kjenner til som beskatter Røde Kors-delegater som om de skulle bo i hjemme. Jeg har også erfaring for at man kan bli mistenkt for å lure unna inntekt fra beskatning, slik at det blir ekstra bry med dokumentasjon etc.

Når alt dette kommer i tillegg til at tjeneste ute teller lite faglig, både formelt og generelt, bør man i det minste gjøre yngre leger klar over problemene, slik at de tar dette med i overveielsene dersom de skulle være motivert for utenlandsoppdrag.

Som styremedlem og visepresident i Leger uten grenser har Karianne Flaatten et godt utgangspunkt for å gjøre noe med permisjonsregler, pensjonsrettigheter og merittering i tjeneste ute.

Norge som nasjon er opptatt av humanitært arbeid, men legger ikke forholdene til rette for dem som reiser ut, snarere tvert imot. Det må det gjøres noe med.

Tor H. Kristiansen

Flekkefjord

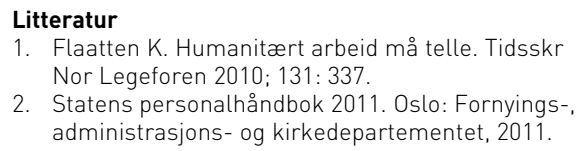

\section{Eli Bergs bok er viktig for alle allmennpraktikere}

Per Vaglum har nok ikke oppdaget innretningen i Eli Bergs siste bok i anmeldelsen sin i Tidsskriftet nr. 4/2011 (1). Sammenhenger er ikke ment å gi ny kunnskap, den skal stimulere oss allmennpraktikere til å legge om praksis (2). Forhåpentligvis blir den toneangivende for hvordan norsk allmennmedisin utvikler seg.

Eli Berg har vært allmennpraktiker på Kongsvinger i 25 år, fra 1975. Hun skriver at hun drev sin kliniske virksomhet mest mulig slik hun hadde lært på Universitetet i Oslo. Etter hvert ble hun mer og mer misfornøyd med den behandlingen hun ga en ganske stor gruppe av de pasientene som hadde såkalte funksjonelle lidelser. Hun utredet dem slik hun hadde lært, men konklusjonen ble ofte uklar. Og viktigere enn det - mange av dem kom snart tilbake med nye lidelser. Når alvorlig organisk sykdom ble utelukket, var disse pasientene sjelden lykkelige over det, og ofte flyttet plagene over til andre organer.

Hun begynte å snakke med dem om deres liv. I boken skildrer hun først og fremst den prosessen hun selv har gjennomgått. Hun startet smått og forsiktig med å spørre om hvordan pasientene hadde det, om traumer i livshistorien og om plagenes relasjon til stress. I 2005 tok hun doktorgraden på disse kliniske studiene med Det skapende mellomrom, om rommet mellom pasient og lege der viktige ord kan utveksles.
Sammenhenger inneholder noen levende kasuistikker. Forbindelsen mellom livshistorie og kroppslige plager var langt fra klar for disse pasientene. En av dem kom med anfall av tung pust som syntes å være livstruende astma. Auskultasjonen var imidlertid normal. Han svarte unnvikende på spørsmål om sitt liv. Etter hvert kom det frem at han var vokst opp i en liten bygd der han var mobbeoffer. Han og broren ble banket av far og hatet av mor. Eli Berg var da stipendiat og kunne følge ham til hjembygda. Etter gjensyn med slektninger og naboer, og etter å kunne sette ord på opplevelser i oppveksten, gikk de kroppslige plagene over.

Så mye kan vi ikke yte for disse pasientene. Programmet hennes er likevel gjennomførbart. Kort kan det beskrives som å følge pasienten gjennom nåtid og eventuelt fortid, å bli med dem på gjenoppdaging, lytte, stille noen få spørsmål, være med.

Eli Bergs bok trekker oss med på en begeistret skildring av utviklingen til en kollega på et viktig og forsømt felt av allmennmedisinen - det å hjelpe pasienter til større klarhet når det gjelder sammenhengen mellom kroppslige plager og livshistorie. Den stimulerer oss til å tenke nøyere over hva vi selv gjør, og kan påvirke oss til å yte bedre hjelp overfor en gruppe pasienter som ofte vil ha et enormt utbytte av innsatsen vår. Den anbefales til alle klinisk aktive leger.

\section{Bjørgulf Claussen}

Institutt for helse og samfunn

Universitetet i Oslo

\section{Litteratur}

1. Vaglum P. Viktig kunnskap gienoppdaget. Anmeldelse av: Berg E. Sammenhenger. Om erfaring. sykdom og medisinsk praksis. Tidsskr Nor Legeforen 2011; 131: 369

2. Berg E. Sammenhenger. Om erfaring, sykdom og medisinsk praksis. Oslo: Gyldendal Akademisk, 2010.

\section{Chlamydiainfeksjon i Sør-Trøndelag - behandling og oppfølging}

I Tidsskriftet nr. 5/2011 omtalte Ghaderi og medarbeidere manglende reseptuttak etter positiv chlamydiaprøve i Sør-Trøndelag i perioden 2004-06 (1). Av dem med positiv prøve hentet $87 \%(1681 / 1920)$ av kvinnene og $74 \%$ (909/1 207) av mennene ut antibiotika innen fire uker etter at prøven var analysert. De nevner at én mulig feilkilde kan være dobbeltresept til en av to partnere. Det er en mindre trolig feilkilde. Dobbelresept gis til partner som ikke søker lege og derfor ikke blir undersøkt for chlamydiainfeksjon.

En annen feilkilde nevnes ikke. Behandling av diagnostisert eller mistenkt chlamydiainfeksjon er gratis, og antibiotika kan gis direkte til pasienten uten registrering i Reseptregisteret. Dette ble gjort på Olafiaklinikken i perioden 2004-06. De siste årene har imidlertid apoteket krevd navneliste over mottakerne for å få medisinen gratis til poliklinikken ifølge blåreseptforordningen. Ved venereaklinikken ved St. Olavs hospital var dette kravet innført allerede før 2004. Det er derfor mulig at registrering i Reseptregisteret var mer fullstendig i Sør-Trøndelag enn i Oslo disse årene.

Hva kan man så gjøre for å motivere pasientene til ta medisinen? Smittevernloven pålegger legen å utføre smitteoppsporing ved påvist chlamydiainfeksjon. En ubehandlet pasient med positiv chlamydiaprøve må derfor gis time for behandling og smitteoppsporing, og pasienten får ved denne samtalen medisinen $\mathrm{i}$ hånden. Pasienten må få klar beskjed om å avstå fra samleie med ubehandlede partnere til også disse har fullført kuren. Legen må ha et lager av antibiotika på kontoret, dette kan fylles på ved å sende liste til apoteket over dem som har fått gratis medisin ifølge $\S 4$ i blåreseptforordningen.

Engangsdose azitromycin bør ikke gis mot genital chlamydiainfeksjon og ikkegonoreisk uretritt på grunn av resistensdrivende effekt (2). I en nylig publisert studie er det dessuten vist dårligere effekt av azitromycin i engangsdose mot genital chlamydiainfeksjon enn en uke med doksycyklinbehandling (3).

Hvis behandlingen er tatt og smitteoppsporing og behandling av partnere utført, er kontrollprøve etterpå mindre viktig. Europeiske og amerikanske retningslinjer for genital chlamydiainfeksjon anbefaler ikke kontrollprøve $(4,5)$. Imidlertid anbefales en kontrollprøve etter tre måneder for å avdekke reinfeksjon. En slik kontrollprøve kan med fordel tas hjemme og prøven sendes til legekontoret for videre distribusjon til laboratoriet.

\section{Harald Moi}

Oslo universitetssykehus

Universitetet i Oslo

Olafiaklinikken

Litteratur

1. Ghaderi S, Nordbø SA, Bakken IJ Chlamydiainfeksjon i Sør-Trøndelag - behandling og oppfølging. Tidsskr Nor Legeforen 2011; 131: 461-3.

2. Moi H. Reduser bruken av azitromycin som engangsdose. Tidsskr Nor Legeforen 2011; 131 $673-4$.

3. Schwebke JR, Rompalo A, Taylor S et al. Re-evaluating the treatment of non-gonococcal urethritis: emphasizing emerging pathogens - a randomized clinical trial. Clin Infect Dis 2011; 52: 163-70.

4. Lanjouw E, Ossewaarde JM. Stary A et al. 2010 European guideline for the management of Chlamydia trachomatis infections. Int J STD AIDS 2010 21: 729-37

5. Workowski KA, Berman SM. Sexually transmitted diseases treatment guidelines, 2010. MMWR Recomm Rep 2010; 59: 44-9. 